\title{
POLSKA! BIAŁO-CZERWONI!
}

DARIUSZ KOSIŃSKI

Wydział Polonistyki Uniwersytetu Jagiellońskiego;

Faculty of the Polish Studies of the Jagiellonian University (Poland)

dkkd@poczta.onet.pl

Kilkakrotnie już wyrażałem żal, że w opublikowanej w roku 2010, ale skończonej już w lutym 2009 książce Teatra polskie. Historie, w której na pięciuset stronach nie zajmowałem się niczym innym tylko Polską jako przedstawieniem, nie podjąłem tematu widowisk sportowych. Stało się tak częściowo z powodu braku miejsca (książka i tak ma rozmiary niemal monstrualne), także z powodu kompozycji, która - jak mi się wydawało - nie stworzyła dogodnej przestrzeni dla prezentacji tej złożonej i wieloaspektowej tematyki. Z perspektywy czasu widzę, że jest to jeden z poważniejszych błędów, jakie popełniłem. Po pierwsze, ów brak kontynuuje i podtrzymuje tradycję lekceważenia widowisk sportowych przez badaczy zajmujących się kulturą i sztuką, poświęcających czas i energię na analizę najdrobniejszych niuansów dzieł i zjawisk cieszących się prestiżem i zaliczonych do „wysokich”, a łatwo i lekko pomijających kulturę popularną i jej wytwory skutecznie wpływające na światopogląd, nawyki i wyobrażenia kulturowe milionów. Osobiście jestem zdania, że stoi za tym fałszywe poczucie wyższości i bardzo niewygodnie mi z tym, że sam mogę być o nie podejrzewany. Po drugie, już po napisaniu książki doszedłem do wniosku, że to właśnie widowiska sportowe, a dokładniej - dramatyzacje i przedstawienia tworzone w ich trakcie przez kibiców - stanowią współcześnie istotne narzędzie performatywnego ustanawiania wspólnoty narodowej, że - mówiąc innymi słowy - widownie 
sportowe to najbardziej masowy współczesny teatr narodowy. W swoim artykule chciałbym ten brak przynajmniej częściowo nadrobić.

Dla teatrologa czy też - jak wolałbym się nazywać - badacza dramatów i przedstawień widowiska sportowe stanowią obszar prawdziwe fascynujący z wielu powodów, także teoretycznych. W znacznym stopniu pozwalają one na przykład zakwestionować sens jednego z podstawowych teatrologicznych pytań: kto jest widzem, a kto aktorem, gdzie jest scena, a gdzie widownia, jednocześnie (i w tej jednoczesności widzę aspekt bardzo ważny) znosząc zbyt prosty podział na widzów (jak w teatrze) i uczestników (jak w rytuale i zabawie). Kibice sportowi są oczywiście widzami (nie oni przecież odbijają piłkę, strzelają bramki czy skaczą na nartach), ale też są uczestnikami i współtwórcami widowiska, czasami wręcz kradnąc show rzekomo głównym wykonawcom.

W Polsce na złożoność widowisk sportowych zwracał swego czasu uwagę Zbigniew Raszewski, który zaliczał je do grupy widowisk zwanych ,zawodami” i precyzyjnie opisywał jako ,pozornie zamknięte” - uczestnicy zawodów skupieni są na rywalizacji i w zasadzie mogliby się obyć bez widzów (mają przecież miejsce mecze przy pustych widowniach), ale zarazem czynią bardzo wiele, by zwrócić ich uwagę i wzbudzić podziw dla swoich umiejętności. Od czasów Raszewskiego dużo się w tej dziedzinie zmieniło, zwłaszcza w związku z rozwojem masowych widowisk sportowych rządzonych i organizowanych przez telewizję, których wzorem jest piłkarska Liga. Pojawienie się masowej widowni telewizyjnej i prawdziwa powódź transmisji zawodów doprowadziły do zasadniczej zmiany położenia, roli i funkcji widzów obecnych na trybunach stadionów, hal czy skoczni. Relacje między poszczególnymi grupami aktorów widowiska sportowego są dziś o wiele bardziej złożone i dynamiczne. Nie jest przecież tak, że zawsze najważniejsi są sportowcy: niekiedy większymi gwiazdorami są trenerzy (casus José Mourinho), a w bardzo wielu przypadkach od tego, co dzieje się na arenie sportowej, ważniejsze są wydarzenia na widowni. Nie chodzi przy tym tylko o różnego rodzaju 
ekscesy, ale także o planowe akcje performatywne, na przykład takie, jakie urządzają mistrzowie Polski kibiców piłkarskich, czyli fani Lecha Poznań. Z perspektywy widowiska telewizyjnego wszystko, co znajduje się i wydarza na arenie sportowej i w jej otoczeniu tworzy materiał, z którego montowany jest produkt końcowy wystawiany na ekranach telewizorów. Myliłby się jednak ten, kto uznałby, że widz telewizyjny, będący „siedliskiem montażu” (by użyć terminu Jerzego Grotowskiego), przypomina swą bierną postawą widza dawnego teatru. Wszyscy przecież wiemy, że tak nie jest, a każdy prawdziwy kibic nie raz oburzał się na niezrozumiałe narzekania rodziny i polecenia, by „zachowywać się normalnie”. Stanem normalnym widza-kibica nie jest oglądanie i podziwianie, lecz bycie w ciągłej aktywności, która określa się zazwyczaj bardzo teatralnym terminem: przeżywanie.

Ten krótki zarys niezwykle złożonej i bogatej, a czekającej na swego badacza teorii współczesnego widowiska sportowego wydaje mi się koniecznym wprowadzeniem do zasadniczego tematu, który chcę podjąć, a mianowicie do opisu i analizy przedstawień kibiców polskiej reprezentacji narodowej. Teoretycznym punktem wyjścia jest dla nich bowiem przekonanie, że działania kibiców nie stanowią dodatku czy tła dla występów sportowców, ale tworzą całość niemal autonomiczną, posiadającą własne cele i realizującą własne znaczenia i wartości, w pewnym stopniu niezależne od celów, znaczeń i wartości zawodów. Mówiąc krótko: o ile sportowcom zależy na zwycięstwie i pokazaniu swych niezwykłych umiejętności, o tyle kibice dążą przede wszystkim do ustanowienia i jednoczesnego wystawienia wspólnoty obdarzonej szczególna mocą.

Zanim przyjrzę się tym działaniom z bliska, muszę jeszcze wyjaśnić, że przedmiotem swojego opisu i analiz przeprowadzanych w tym artykule uczyniłem przede wszystkim akcje kibiców piłki siatkowej. Oczywiście wiem, że najpopularniejszą dyscypliną sportu pozostaje w Polsce wciąż piłka nożna, ale siatkówka również cieszy się wielką popularnością, a stanowi przykład o tyle wdzięczny, że zjawisko masowego kibicowania polskiej reprezentacji, 
choć stosunkowo nowe, niemal od razu wykształciło bardzo klarowne i wyraziste formy performatywne, stanowiące rodzaj totalnego teatru narodowego. Wiąże się to z wieloma czynnikami, wśród których z pewnością ważną rolę odgrywa specyfika samych zawodów pozostawiających kibicom stosunkowo dużo czasu do dyspozycji i odbywających się w zamkniętych halach. Warunki te wymuszają na uczestnikach bardziej domowe, cywilizowane zachowania, nie takie, na które pozwalają otwarte stadiony piłkarskie. Ważną cechą siatkówki jest też to, że stanowi ona sport techniczny i taktyczny, precyzyjnie rozplanowany w przestrzeni i w zasadzie całkowicie bezkontaktowy (jeśli nie liczyć przypadkowych zderzeń zawodników, potrąceń itp.). W efekcie sport ten jest relatywnie mało agresywny, spośród popularnych sportów drużynowych z udziałem piłki najdalszy od analogii wojennych. Siatkówce bliżej do szachów niż do pola bitwy, co także przekłada się na zachowania kibiców, raczej pokazujących swoje zaangażowanie w dobrą zabawę, niż rzeczywiście rywalizujących ze sobą.

Podobnie jak w przypadku piłki nożnej, na rozwój performansów kibicowskich znaczny wpływ miał też rozwój masowych widowisk telewizyjnych z Ligą Światową na czele. Odbywające się coraz częściej mecze na wysokim poziomie sprawiają, że mamy więcej okazji do kibicowania, zaś obrazy dobrej zabawy w siatkarskich halach skutecznie przekonują, by się do niej włączyć. Oczywiście nie bez znaczenia jest też fakt, że polskie reprezentacje siatkarskie odnosiły w ostatnich latach znaczne sukcesy na arenie międzynarodowej, ale osobiście nie sądzę, by był to warunek sine quo non.

Czas już chyba najwyższy, by zajrzeć do hali i zobaczyć, co robią kibice. Oto najważniejsza polska arena performansów siatkarskich - katowicki Spodek w trakcie meczu Polska-Francja. Prawdziwa demonstracja polskości - wielotysięczny tłum w barwach narodowych wyśpiewujący, no właśnie - co? Powtarzający się śpiew „Polska! Biało-czerwoni!” nie niesie z sobą właściwie żadnego znaczenia, żadnej treści. Jest rodzajem oksymoronicznego dodatku do zainscenizowanego widoku. Oto tysiące Polaków ubranych 
w biało-czerwone stroje i unoszących w górę biało-czerwone szaliki, flagi i plansze wyśpiewują słowa będące performatywnym samookreśleniem ustanawiającym wspólnotę biało-czerwonych: Polskę. W pewnym sensie jest to odpowiednik innego performatywu: zawołania „Tu jest Polska!” znanego z nacjonalistycznych demonstracji, jednak w wydaniu kibiców nie ma on znamion wykluczenia, owego domyślnego: ,a tam jej nie ma!” (bo tam, na przykład stało ZOMO). Wprost przeciwnie: Polska to biało-czerwoni - wspólnota pozbawiona wszelkich innych oznak, wszystkiego, co mogłoby wprowadzać zróżnicowanie. Dokonuje się tu znaczące i brzemienne w skutki przesunięcie: znak przynależności narodowej, element wynalezionej tradycji - biało-czerwone barwy - staje się rdzeniem procesu budowania tożsamości, wokół którego konstytuuje się wspólnota o charakterze radykalnie inkluzywnym. Umieszczenie znaku w punkcie rdzenia sprawia, że identyfikacja narodowa ustanawiana przez pokazany przed chwilą masowy performans tworzona jest w działaniu i przez działanie wokół przysłoniętej znakiem pustki. Biało-czerwone barwy występujące w funkcji twardego rdzenia wspólnoty narodowej, będącej - według jej wyznawców - czymś przyrodzonym i naturalnym zarazem zasłaniają i odsłaniają fakt, że jest ona czymś wciąż konstruowanym i rekonstruowanym, a więc w istocie odsłaniają brak rzekomo „,naturalnego” zakorzenienia etnicznego stanowiącego fundament tradycyjnego rozumienia patriotyzmu. Narodowy teatr kibiców stanowi masową celebrację narodu jako wspólnoty ustanawiającej się w działaniu, a więc nie przedustawnej i „odwiecznej”, ale powstającej tu i teraz. Jako ta wspólnota, oparta na aktualnym działaniu, jest zdolna do przyjmowania każdego, kto spełni podstawowy warunek: włączy się do akcji. Każdy, kto wstanie i zaśpiewa z chórem „Polska! Biało-czerwoni!” staje się częścią wspólnoty: biało-czerwonym, Polską.

Przyjęcie tej wstępnej tezy wskazuje na konieczność przyjrzenia się działaniu, a więc zobaczenia, „co robią ludzie, kiedy właśnie to robią”. Przez odniesienie się do tego podstawowego zadania performatyki autorstwa 
Richarda Schechnera, chciałbym mocno podkreślić, że właśnie metodologia performatyczna pozwala moim zdaniem na wyjście poza fałszywe rozumienie występów, przedstawień, dramatyzacji i celebracji związanych $\mathrm{z}$ tożsamością narodową jako ekspresji istniejącej uprzednio rzeczywistej wspólnoty. Tożsamość narodowa tworzy się w serii działań, które nie są jej wyrazem, znakiem, lecz sposobem istnienia. Dlatego badając działania, nie analizujemy znaczącego wskazującego na istniejące gdzie indziej (np. w wieczności czy naturze) znaczone, ale badamy sposób istnienia elementów rzeczywistości, która ma charakter dramatyczno-przedstawieniowy $\mathrm{i}$ istnieje jako okazywane działanie.

Dominującym i zarazem podstawowym sposobem ustanawiania wspólnoty narodowej kibiców reprezentacji jest, jak już wspomniałem, wykorzystanie w funkcji rdzenia znaków przynależności narodowej. Szczególne znaczenie mają tu biało-czerwone barwy dominujące w strojach kibiców, wykorzystywane także w makijażach, a nawet fryzurach. Totalną dominację tych dwóch podstawowych kolorów zapewniają też organizatorzy meczów, którzy kładą na krzesełkach arkusze A4 w kolorach białym (na górnych rzędach) i czerwonym (w rzędach dolnych). W odpowiednich momentach na znak dany przez wodzireja (za chwilę powiem o nim więcej) kibice podnoszą w górę owe arkusze, zamieniając salę w wielką biało- -czerwoną całość - uwidocznioną metonimię Polski.

Drugim obok barw narodowych znakiem organizującym wspólnotę jest hymn, na meczach siatkarskich śpiewany od niedawna w ten sam, bardzo charakterystyczny sposób. Zamiast wykorzystania nagrania z taśmy, wykonania przez orkiestrę czy popularną piosenkarkę Mazurek Dąbrowskiego odśpiewują w halach siatkarskich sami zgromadzeni, którym tylko na samym początku akompaniator podrzuca tonację. W efekcie zlikwidowana zostaje tak często bolesna dominacja nagłośnionego wykonania zawodowego nad śpiewem wspólnotowym. Chóralne śpiewanie hymnu staje się totalnym działaniem, aktywizującym wszystkich obecnych, łączącym sportowców 
i kibiców w jedność, zwróconą ku czemuś trzeciemu, co ich ogarnia i zarazem podporządkowuje. Tym czymś jest oczywiście Polska. Jest tu ona nie oznaczana przez symboliczną pieśń, ale fizycznie, zmysłowo doświadczana dzięki uczestnictwie w masowym chórze o ogromnej, bezpośredniej, fizjologicznej sile oddziaływania. Chóralny śpiew przemienia znak umieszczony w pozycji rdzenia w bezpośrednie doświadczenie Polski jako potęgi tworzonej przez nas - biało-czerwonych.

By wzmocnić to poczucie potęgi, siatkarskie mecze reprezentacji Polski wytworzyły także specyficzne stałe działania performatywne o charakterze quasi-rytualnym czy quasi-magicznym. Kibicowanie to przecież, co wiadomo od dawna, nie tylko wyraz wsparcia udzielanego jednej z drużyn, lecz także cały ciąg performatywnych aktywności mających na celu bezpośrednie oddziaływanie na przebieg wydarzeń. Racjonalnie rzecz ujmując, chodzi tu o oddziaływanie psychologiczne, ale z antropologicznego punktu widzenia trudno wątpić, że kibice spełniają funkcje czarowników i szamanów, zapewniających przychylność niebios. Element ten jest szczególnie widoczny w przypadku siatkówki - gry, w której spore znaczenie odgrywają elementy nieracjonalne i przypadkowe. Jako taka siatkówka jest szczególnie podatna na „zamawianie” rzeczywistości, które w przypadku polskiej reprezentacji i jej kibiców ma charakter przywołania mocy przodków, a więc czegoś, co można by uznać za odpowiednik rytuałów opętania, w których duch przodków wstępujący w wyznawców daje im szczególną moc. Taki właśnie charakter ma kolejny stały punkt występów polskich kibiców siatkówki, a mianowicie chóralne wykonanie pieśni $W$ stepie szerokim z filmu Pan Wołodyjowski, które następuje zawsze wtedy, gdy polska drużyna przechodzi ciężki chwile, gdy traci ducha i zaczyna przegrywać. Pieśń tę zaczęto wprawdzie śpiewać w nieco innych okolicznościach, odnosząc ją początkowo bezpośrednio do byłego trenera kadry narodowej - Raula Lozano, człowieka, jak powiedziałby pewnie pan Zagłoba, nikczemnego wzrostu. 
Dość szybko zyskała ona jednak charakter niby-magiczny i związała się $\mathrm{z}$ momentami kryzysowymi w grze reprezentacji.

Nieco innym przykładem działań z tej samej grupy jest przyśpiewka wykonywana w chwilach szczególnie ważnych, przy decydujących piłkach. Jej prosty tekst powtarzany kilkakrotnie brzmi: „W górę serca, Polska wygra mecz!" Połączenie kulturowych znaków jest tu doprawdy karkołomne: na melodię Yellow submarine śpiewany jest tekst wykorzystujący kościelne Sursum corda w funkcji zawołania sportowego. Ocieram się tu być może o granice wrażliwości religijnej, jednak jest to bez wątpienia zabawowe, ale mimo wszystko ciągle odwołanie do przekonania o szczególnej opiece sił nadziemskich, która może zapewnić Polsce zwycięstwo.

I właśnie zabawa stanowi w performansach kibiców siatkarskich (i nie tylko) siłę zasadniczą. Przy czym od razu zauważyć trzeba, że zgodnie z tezami wielu antropologów i performatyków zabawa graniczy tu z rytuałem. Kibice z pewnością się bawią, ale zarazem ich zabawa z równą pewnością uznana być powinna za rytuał: powtarzane według określonego wzoru działania służące realizacji wartości należących do „życia poważnego”, w omawianym przypadku: rytuał potwierdzający i umacniający wartości ważne dla danej wspólnoty.

Kibicowanie, nie przestając być zabawą, ma - podobnie jak rytuał - wyraźne strukturalne wzorce i ma też swoich „kapłanów”. Są nimi wodzireje, pełniący role didaskalosa i koryfeosa, a więc artystów nauczających i prowadzących chór. Świadomie używam nazw zaczerpniętych z tradycji teatru starożytnej Grecji, bo jestem przekonany, że trzeba o nim myśleć właśnie tak - jako o czymś podobnym do naszych zawodów sportowych. Wprawdzie środki używane przez współczesnych koryfeuszy nie są wyrafinowane (elektroniczny keyboard i takież bębny, proste melodie i gesty), ale też praca z thumem nie pozwala na stosowanie skomplikowanych i subtelnych sposobów oddziaływania, co jednak wcale nie znaczy, że jest łatwa. Koryfeusze muszą przecież reagować na bieżąco na zachodzące na parkiecie i widowni 
zdarzenia: uruchamiać stałe elementy programu, oczekiwane w określonych momentach przez kibiców, ale też nadążać za zmiennym rytmem meczu, a nawet tworzyć napięcie tam, gdzie go brakuje, dostarczając kibicom pożywki do zabawy, gdy zawodnicy zbyt łatwo rozprawiają się ze słabymi przeciwnikami.

Jak można zauważyć, opisana tu w skrócie kibicowska zabawa ma charakter karnawalizacji. Oto w wydzielonej przestrzeni i w wydzielonym czasie ludzie porzucają swoje codzienne role, przekształcają się w tzw. figury liminalne, o zniekształconych twarzach i hipertroficznych ciałach, by doświadczyć niezróżnicowanej wspólnoty. Najlepiej, jak sądzę, można ją określić zapożyczonym od Victora Tunera terminem communitas, który opisuje wspólnotowe doświadczenie bycia razem w sposób całkowicie egalitarny, oparty na bezpośredniej i spontanicznej relacji jednostek ludzkich między sobą, powiązany z doświadczeniem przepływu (flow) i związany z zawieszeniem strukturalnych relacji międzyludzkich rządzących życiem codziennym. „Communitas - pisał Tuner - to spontanicznie generowany stosunek między zrównanymi i równymi, totalnymi i zindywidualizowanymi istotami ludzkimi, pozbawionymi atrybutów strukturalnych" i jako takie wiązał je w sposób szczególny z liminalnością. Communitas skarnawalizowana ma przy tym charakter świata na opak, odwracającego wartości i relacje dominujące w życiu codziennym, w sferze rozciągającej się poza wyróżnionym, świątecznym czasem i miejscem.

Widziana $\mathrm{z}$ tej perspektywy communitas kibiców reprezentacji jawi się jako odwrócenie modelu patriotyzmu przeważającego w polskim życiu zbiorowym: patriotyzmu poważnego, smutnego i cierpiętniczego, związanego $\mathrm{z}$ ofiarą i poświęceniem, zarażonego śmiercią, która uznawana jest za konieczną do pozagrobowego zwycięstwa. Performanse tego ciężkiego

${ }^{1}$ V. Turner, Gry spoleczne, pola i metafory. Symboliczne działanie w spoteczeństwie, thum. W. Usakiewicz, Kraków 2005, s. 169. 
patriotyzmu politycznego mają charakter konfliktowy, zdecydowanie ekskluzywny, opierają się na opozycji „my - oni” i na fantazmacie prawdziwych Polaków. Są podsiąknięte agresją i całkowicie pozbawione poczucia humoru. Co ciekawe, zwłaszcza ostatnio, wcale nie sięgają chętnie po barwy narodowe, lecz raczej po mesjanistycznie reinterpretowany krzyż, zastępując radosnego Mazurka Dąbrowskiego, ciężkim Boże coś Polskę, z koniecznie zmienioną ostatnią strofą.

W zamkniętej przestrzeni hali sportowej w trakcie karnawałowej zabawy ustanawiana i doświadczana jest Polska zupełnie inna: radosna i pewna siebie, zwrócona raczej w przyszłość niż w przeszłość, Polska, która nie rozpamiętuje klęsk, ale oczekuje zwycięstwa, reagując na przegraną śpiewem „Nic się nie stało, Polacy, nic się nie stało", z którego oczywiście można drwić, ale który oznacza nic innego, jak tylko zdecydowane przekreślenie tak podobno typowej dla naszego charakteru narodowego skłonności do przyjmowania malowniczej figury niewinnej ofiary cierpiącej za świat. Co wydaje mi się bardzo ważne, to fakt, że doświadczenie to jest udziałem tysięcy ludzi zgromadzonych w halach, milionów zasiadających przed telewizorami i że dostarcza koniecznej dla zdrowia społecznego równowagi.

Należy mocno podkreślić, że w performansach kibiców Polska doświadczana jest jako potęga niezależnie od przebiegu wydarzeń na boisku, ponieważ Polska pozostaje wielka dzięki kibicom i ich działaniom. Tłum śpiewający „Polska wygra mecz!” ustanawia to zwycięstwo niezależnie od rzeczywistego przebiegu zmagań. „Polska wygra mecz”, ponieważ tworzą ją kibice - „Biało-czerwoni”, a ci nigdy się nie poddają i negują najbardziej nawet oczywiste klęski.

Co wydaje mi się bardzo ciekawe, to fakt, że polscy kibice sami są świadomi roli, jaką pełnią w życiu zbiorowym, a także tego, że ich działania mają większe znaczenie i stoją często na wyższym poziomie niż osiągnięcia sportowców. Dowodzi tego krążący po Internecie nieoficjalny hymn polskich kibiców reprezentacyjnych, pod jasno sformułowanym tytułem 
Biało-czerwoni ( $W$ jedności Polska). Jest to zarazem swoista synteza tego, o czym dotąd mówiłem i przykład narodowej sztuki popularnej, miejscami mocno nieporadny warsztatowo, miejscami wręcz w tej nieporadności groteskowy, ale o wiele precyzyjniej niż propozycje sztuki wysokiej ujmujący zmiany zachodzące w sposobach konstruowania tożsamości narodowej. Oto tekst tej pieśni autorstwa Zuzanny Szreder:

Po walkach znamy porażek smak

W smutku przetrwamy pucharu brak

$\mathrm{Z}$ orłem na piersi wspieramy was

W końcu nadejdzie wygranej czas

Biało-czerwony wulkan wybucha

A Polska wierzy i ufa

Pokażmy światu pazurek

Niech zabrzmi Polski Mazurek

Kibice wasi z zachodu, północy, południa i wschodu

$\mathrm{W}$ jedności razem czuwają i z dumą was oglądają

Dla polskich marzeń, uczuć i serc

Atakiem wiary zwycięstwu lżej

Będą dni chwały, radości, łez

Szampańskim balem uczcimy grę ${ }^{2}$

Przy całej naiwności tego tekstu bez trudu można zauważyć, że zawiera on wszystkie elementy, o których dotąd mówiłem, ujęte jednak w specyficzną

${ }^{2}$ Tekst cytowany za portalem tekstowo.pl, http://www.tekstowo.pl/piosenka,zuzanna_szreder,bialo_czerwoni.html (data dostępu: 20.05.15); na portalu Youtube można też obejrzeć odpowiednią ilustrację w postaci wideo: https://www.youtube. com/watch?v=OOCJD7Rt4UE (data dostępu: 20.05.15). 
całość, rodzaj pasażu od teraźniejszości do przyszłości. Oto dziś „,znamy porażek smak" i brak nam pucharu, ale dzięki wierze kibiców, ich jedności i dumie, w przyszłości możliwy będzie „szampański bal”, czczący dni chwały. Jeśli teraz to mesjańskie przesłanie zestawić z omawianymi wcześniej działaniami kibiców (filmowy efekt takiego zestawienia bez trudu można znaleźć na Youtube), to nasuwa się wniosek, że ich karnawałowa zabawa ma charakter performatywnego spełniania przepowiedni i zapewniania dni chwały już tu i teraz. Skoro - jak głosi powtarzane nieustannie przekonania - „polscy kibice są najlepsi na świecie”, to jest to nieomylny znak, że zapowiedziana i obiecana erupcja polskiego wulkanu już następuje, co zresztą potwierdza czas teraźniejszy użyty w refrenie. Kto ową erupcję i łzy radości zapewnia? Polscy kibice. Biało-czerwoni.

To, co zdołałem przedstawić, to oczywiście tylko wierzchołek góry lodowej. Zagłębiając się w nią, należałoby się w pierwszej kolejności zająć fenomenem Adama Małysza - polskiego bohatera łączącego w niezwykły konglomerat elementy religijne, romantyczny mit lotu i prostego człowieka z ludu z całą groteskowością swojego ciała i karnawałowej oprawy dyscypliny, którą uprawia. Trzeba by też zająć się o wiele groźniejszymi zachowaniami kibiców piłkarskich, konsekwentnie budujących wspólnoty zorganizowane wokół konfliktów i coraz silniej odwołujących się do tradycji nacjonalistycznych. Warto by też uważniej przyjrzeć się performansom narodowym opisanym powyżej, zwracając uwagę na ich aspekt rodzinny (powracające ujęcia rodzin i rodziców z dziećmi wspólnie kibicujących „naszym”), a także na patriarchalne zaplecze (nawet na meczach reprezentacji kobiecej śpiewa się „Polska. Biało-czerwoni”, a nie „Polska. Biało-czerwone”). Wszystko to i wiele innych jeszcze tematów czeka na swoich badaczy, więc może jednak warto wyjść z bibliotek i teatrów i zająć się tym, co ludzie robią? 


\section{Bibliografia}

Dariusz Kosiński, Teatra polskie. Historie, PWN, Warszawa 2010.

Victor Turner, Gry spoleczne, pola $i$ metafory. Symboliczne działanie w społeczeństwie, tłum. W Usakiewicz, Kraków 2005. 


\section{Poland! White and Red!}

The article attempts to analyze sport performances as the space and tool of producing and establishing national identity. From this perspective the author interprets the performances by the fans of Polish national volleyball team. They are seen as the effective creations of open and joyful patriotism, opposite to the grave, sacrifical and nationalistic patriotism growing out of the pararitualistic postromantic traditions.

Keywords: sport performances, national identity, patriotism, sport fans, voleyball matches. 


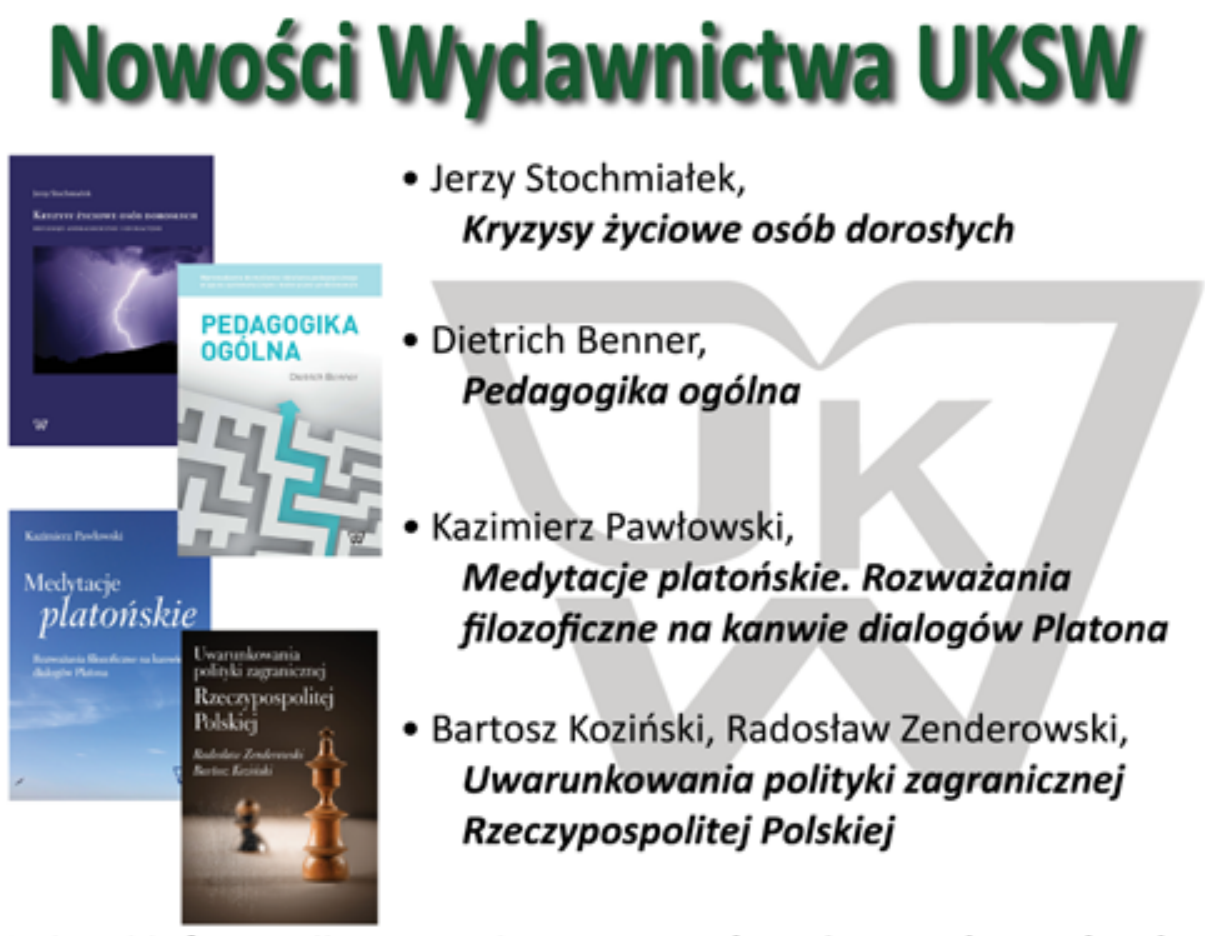

Więcej informacji na stronie: www.wydawnictwo.uksw.edu.pl 